\title{
Immune Thrombocytopenic Purpura
}

Teny Tjitra Sari

Departemen Ilmu Kesehatan Anak Fakultas Kedokteran Universitas Indonesia/Rumah Sakit Dr. Cipto Mangunkusumo, Jakarta

Immune thrombocytopenic purpura (ITP) telah mengalami perubahan definisi dan klasifikasi. Definisi ITP sebagai jumlah trombosit $<100.000 / \mathrm{uL}$ dengan klasifikasi new diagnosed ITP, ITP persisten, dan ITP kronik. Disregulasi imun ITP menyebabkan menurunnya jumlah megakariosit di sumsum tulang dan trombosit di darah tepi. Diagnosis ditegakkan secara klinis dan pemeriksaan penunjang. Berbagai penelitian telah menunjukkan banyak perubahan pada tata laksana ITP. Bila tidak ada perdarahan ataupun perdarahan ringan, kasus ITP dapat ditatalaksana hanya dengan observasi. Namun demikian, dokter tetap harus dipertimbangkan faktor sosial dalam menentukan pilihan terapi seperti kecemasan orang tua, akivitas anak, dan jarak ke pusat kesehatan. Terapi IVIG dan kortikosteroid tetap menjadi pilihan pertama dalam tata laksana ITP bila terjadi perdarahan berat ataupun mengancam jiwa. Sari Pediatri 2018;20(1):58-64

Kata kunci: ITP, IVIG, kortikosteroid

\section{Immune Thrombocytopenic Purpura}

Teny Tjitra Sari

ITP has undergone a change of definition and classification. ITP has defined as platelet count less than 100,000/uL, with classification as newly diagnosed ITP, persistent and chronic ITP. There is immune dysregulation which lead to reduced megakaryocyte count in bone marrow and platelet count in peripheral blood. Diagnosis was established by clinical manifestations and supportive examinations. There were some studies showed that ITP management has changed. If there were mild or no bleeding, it can be managed with observation alone. Nevertheless, physicians must consider some social factors such as parental anxiety, child activity level, and proximity to the medical. Treatment with IVIG and corticosteroid is still the first line of management ITP with severe or life-saving bleeding. Sari Pediatri 2018;20(1):58-64

Keywords : ITP, IVIG, corticosteroid

Alamat korespondensi: Teny Tjitra Sari. Departemen Ilmu Kesehatan Anak Fakultas Kedokteran Universitas Indonesia/RSCM, Jakarta. Email:t_tjitrasari@yahoo.com 


\section{Definisi dan klasifikasi}

Penyakit ITP merupakan kelainan perdarahan yang disebabkan oleh penurunan jumlah trombosit. Saat awal, ITP merupakan singkatan dari idiopathic thrombocytopenic purpura karena belum diketahui penyebabnya. Dengan perkembangan ilmu diketahui ternyata penyebabnya adalah kelainan imun sehingga singkatan ITP berubah menjadi immune thrombocytopenic purpura. Di beberapa literatur terakhir sering disebut sebagai immune thrombocytopenia. ${ }^{1,2}$

Konsensus International Working Group (IWG) tahun 2007 membuat definisi dan klasifikasi ITP terbaru. Definisi ITP, yaitu keadaan trombosit $<100.000 /$ uL. Hal ini didasari tiga pemikiran bahwa (1) kemungkinan perdarahan pada jumlah trombosit 100.000-150.000/uL hanya sekitar 6,9\%; (2) nilai normal trombosit pada etnik Non-Western adalah sekitar 100.000-150.000/uL; (3) adanya trombositopenia ringan "fisiologik" yang terjadi pada kehamilan.

Selain itu, klasifikasi ITP juga mengalami perubahan menjadi ITP newly diagnosed, ITP persisten dan ITP kronik (Tabel 1). ${ }^{1,2}$ Definisi ITP primer adalah keadaan trombositopenia yang tidak diketahui penyebabnya. Definisi ITP sekunder adalah keadaan trombositopenia yang disebabkan oleh penyakit primer. Penyakit primer yang sering berhubungan dengan ITP, antara lain, penyakit autoimun (terutama sindrom antibodi antifosfolipid), infeksi virus (termasuk Hepatitis C dan human immunodeficiency virus [HIV]), dan obat-obat tertentu (Tabel 2). ${ }^{1,2}$

\section{Patofisiologi ITP}

Penyakit ITP adalah penyakit autoimun yang disebabkan adanya destruksi trombosit normal akibat adanya antibodi (antibody-mediated destruction of platelets) dan gangguan produksi megakariosit. Penyakit ITP merupakan kelainan akibat disregulasi imun dengan hasil akhir adanya hilangnya toleransi sistem imun terhadap antigen diri yang berada di permukaan trombosit dan megakariosit. Sel T teraktivasi akibat pengenalan antigen spesifik trombosit pada APC (antigen presenting cell) yang kemudian menginduksi ekspansi antigen-spesifik pada sel B. Kemudian sel B menghasilkan autoantibodi yang spesifik terhadap glikoprotein yang diekspresikan pada trombosit dan megakariosit. Trombosit yang bersirkulasi diikat oleh autoantibodi trombosit kemudian terjadi pelekatan pada reseptor FC makrofag limpa yang mengakibatkan penghancuran trombosit. Selain itu, terbentuk juga autoantibodi anti megakariosit yang mengurangi kemampuan megakariosit untuk menghasilkan trombosit. ${ }^{3}$ Terjadi produksi autoantibody (A) yang

Tabel 1. Terminologi baru untuk ITP ${ }^{1,2}$

\begin{tabular}{ll}
\hline Terminologi & \multicolumn{1}{c}{ Keterangan } \\
\hline Immune thrombocytopenia & Menggantikan terminologi immune thrombocytopenia purpura \\
Newly diagnosed ITP & Menggantikan terminologi ITP akut (jumlah trombosit $<100.000 /$ uL yang berlangsung \\
& hingga 3 bulan) \\
ITP persisten & ITP (jumlah trombosit $<100.000 / \mathrm{uL}$ ) yang berlangsung 3-12 bulan \\
ITP kronik & ITP yang berlangsung $>12$ bulan \\
\hline
\end{tabular}

Tabel 2. Penyebab ITP sekunder ${ }^{1}$

Sindrom antifosfolipid
Trombositopenia autoimun (contoh Sindrom Evans)
Efek samping pemberian obat
Infeksi Cytomegalovirus, Helicobacter pylori, Hepatitis C, Human Immunodeficiensy virus, varicella zoster
Kelainan limfoproliferatif
Efek samping transplantasi sumsum tulang
Efek samping vaksinasi
Systemic lupus erythematosus




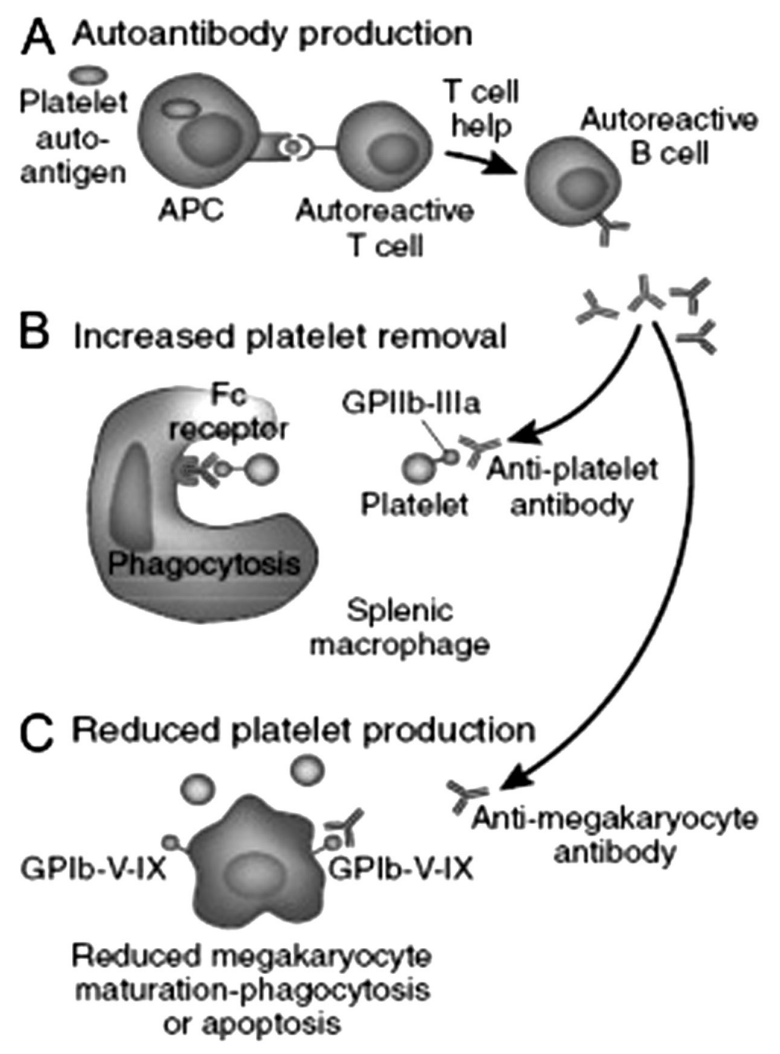

Gambar 1. Mekanisme disregulasi imun pada ITP ${ }^{3}$

meningkatkan penghancuran trombosit oleh makrofag limpa (B) dan menurunnya produksi trombosit akibat antibodi anti-megakariosit (C).

\section{Gambaran klinis ITP}

Pasien ITP mempunyai gambaran klinis yang khas, yaitu terjadi pada anak usia 4-6 tahun yang tampak "sehat" dengan gambaran perdarahan kulit seperti hematom dan petekiae. Sebanyak 75\% pasien datang dengan jumlah trombosit $<20.000 /$ uL. Sebagian besar kasus (hampir 2/3 kasus) mempunyai riwayat penyakit infeksi yang terjadi hingga 4 minggu sebelumnya. Pemeriksaan fisis juga hanya mendapatkan perdarahan kulit akibat trombositopenia. Gambaran darah tepi menunjukkan jumlah trombosit rendah tanpa sel blast. ${ }^{2}$

Frekuensi komplikasi ITP anak hanya 0,2\% atau 1 per 500 kasus. Komplikasi perdarahan intrakranial terjadi pada jumlah trombosit $<10.000 /$
uL. ${ }^{2}$ Komplikasi perdarahan berat hanya terjadi pada $3 \%$ kasus ITP dengan jumlah trombosit $<20.000 /$ uL berupa epistaksis, melena, menorrhagia dan/atau perdarahan intrakranial yang membutuhkan perawatan dan/atau transfusi darah. Bahkan, penelitian lain menemukan bahwa hanya 3 dari 505 kasus $(0,6 \%)$ yang mengalami perdarahan hebat. ${ }^{4}$

Penelitian Yohmi dkk ${ }^{5}$ di RSCM (2007) mendapatkan gambaran klinis ITP adalah lebih sering terjadi pada anak laki-laki $(1,9: 1)$, rerata usia 4,78 tahun. Komplikasi perdarahan yang terjadi adalah petekiae $(89 \%)$, episktaksis (18\%), perdarahan mukosa mulut $(12 \%)$, perdarahan subkonjungtiva $(8 \%)$, hematemesis/melena (6\%), hematuria (5\%).

Penelitian di Amerika Serikat ${ }^{6}$ mendapatkan gambaran klinis ITP, yaitu 52\% anak laki-laki, terutama usia 2-5 tahun $(37,6 \%)$. Komplikasi perdarahan yang terjadi adalah epistaksis $(8,4 \%)$, hematuria $(2,3 \%)$, menoragia $(2,6 \%)$, perdarahan saluran cerna $(2,2, \%)$, perdarahan intrakranial $(0,3 \%)$. Sebagian besar tanpa perdarahan yang berat $(85,8 \%)$.

Penelitian Tarantino $\mathrm{dkk}^{7}$ (2016) juga mendapatkan hasil yang tidak jauh berbeda. Komplikasi perdarahan berat yang terjadi pada pasien ITP anak yaitu perdarahan intrakranial $(0,6 \%)$, perdarahan saluran cerna $(0,4 \%)$, dan hematuria $(1,3 \%)$. Delapanpuluh lima persen pasien ITP anak tidak mengalami perdarahan.

\section{Diagnosis ITP}

Diagnosis ITP ditegakkan setelah penyebab trombositopenia lain dapat disingkirkan. Beberapa infeksi perlu disingkirkan seperti HIV, Hepatitis C, Helicobacter Pylori, dan CMV. Kecurigaan ke arah keganasan dan pengaruh obat seperti valproat, heparin juga harus disingkirkan. Pemeriksaan antibodi antifosfolipid dan lupus anticoagulant harus diperiksa bila gejala ITP menjadi persisten/kronik. ${ }^{8}$

Bila gambaran klinis sangat mendukung ke arah ITP, maka pemeriksaan sumsum tulang tidak perlu dilakukan (Grade 1B). Pemeriksaan sumsum tulang juga tidak dilakukan bila pasien tidak memberikan respon setelah diberikan IVIG (Grade 1B). Pemeriksaan sumsum tulang juga tidak dilakukan sebelum pemberian kortikosteroid atau splenektomi (Grade 2C). Pemeriksaan sumsum tulang dilakukan bila ITP tidak memberikan respons 
dalam waktu 3 bulan (mengarah ke ITP persisten). ${ }^{9}$

\section{Tata laksana pada ITP}

Cuker $\mathrm{dkk}^{1}$ merekomendasikan pasien ITP newly diagnosed dengan trombositopenia berat tetapi klinis tanpa perdarahan/perdarahan ringan sebenarnya tidak perlu diberikan tata laksana khusus. Hal tersebut juga sesuai dengan rekomendasi IWG (Grade 1 B).

"Tanpa perdarahan atau perdarahan ringan", yaitu perdarahan yang hanya terjadi di kulit berupa petekiae dan hematom. Hal ini berdasarkan jarangnya kejadian perdarahan berat, jumlah trombosit tidak dapat dijadikan faktor prediktor perdarahan dan adanya toksisitas terapi. Namun demikian, walaupun jumlah kasus perdarahan berat pada ITP anak yang cukup rendah dan perdarahan yang terjadi hanyalah perdarahan ringan/tanpa perdarahan, dokter tetap perlu memperhatikan faktor yang memengaruhi pertimbangan terapi pada ITP. Faktor yang menjadi pertimbangan, antara lain, kecemasan orang tua, akivitas anak, dan jarak ke pusat kesehatan. ${ }^{9}$

Bila diputuskan untuk hanya melakukan observasi maka yang perlu diedukasi kepada orang tua adalah restriksi aktivitas motorik, penghindaran prosedur khusus (contoh pencabutan gigi), penghindaran obat tertentu yang dapat memperberat perdarahan (contoh aspirin). ${ }^{12}$

Sebagai terapi lini pertama maka dapat diberikan IVIG dosis tunggal atau steroid jangka pendek (Grade $1 \mathrm{~B})$. Penggunaan IVIG bila trombosit perlu ditingkatkan dengan cepat (Grade 1B). ${ }^{1}$ Dosis IVIG adalah 0,8-1 $\mathrm{g} / \mathrm{kg}$ dosis tunggal atau $2 \mathrm{~g} / \mathrm{kg}$ terbagi dalam 2-5 hari. Efek samping pemberian IVIG (15-75)\% kasus adalah nyeri kepala, nyeri punggung, mual, dan demam. ${ }^{3,11}$ Penggunaan IVIG hanya diberikan pada keadaan mengancam jiwa. Di Thailand, pemberian IVIG terbukti merupakan langkah yang cost-effective. ${ }^{13}$ Penelitian Choi dkk ${ }^{14}$ (2016) memperlihatkan respons pemberian IVIG berupa jumlah trombosit $\geq 100.000 /$ uL pada bulan ke 1-3 dapat memprediksi prognosis, baik keadaan trombosit pada bulan ke- 6 dan ke-12 $(\mathrm{p}<0,001)$.

Metilprednisolon diberikan dengan dosis $2 \mathrm{mg} /$ $\mathrm{kg}$ per hari atau $60 \mathrm{mg} / \mathrm{m} 2 /$ hari (maksimal $80 \mathrm{mg} /$ hari) selama 14 hari, dilanjutkan dengan tappering off dan dihentikan selama 1 minggu berikutnya. Kortikosteroid dapat juga diberikan dengan dosis tinggi yaitu metilprednisolon $4 \mathrm{mg} / \mathrm{kg}$ per hari (maksimal $180 \mathrm{mg} / \mathrm{hari}$ ) dibagi 3 dosis selama 7 hari, dilanjutkan 50\% dosis pada minggu kedua, dan tappering off pada minggu ketiga. Kortikosteroid parenteral diberikan metilprednisolon sebanyak 15-30 mg/kg IV (maksimal $1 \mathrm{~g} /$ hari) selama 30-60 menit selama 3 hari. ${ }^{11}$ Efek samping pemberian kortikosteroid adalah hipertensi, nyeri perut dan ulkus peptikum, hiperglikemia, osteoporosis, imunosupresi, insufisiensi adrenal. ${ }^{3}$

Imunoglobulin anti-D tidak dianjurkan oleh anak dengan penurunan hemoglobin akibat perdarahan atau adanya hemolisis autoimun (Grade IC). Pemberian imunoglobulin anti-D hanya digunakan sebagai lini pertama Rh-positif, yang tidak displenektomi (Grade 2B). ${ }^{1}$ Dosis imunoglobulin anti-D adalah $50-75 \mu \mathrm{g} / \mathrm{kg}$ dosis tunggal. Efek samping yang utama pada pemberian imunoglobulin anti-D adalah hemolisis. ${ }^{3}$

Berdasarkan berbagai pertimbangan di atas maka Divisi Hematologi-Onkologi FKUI/RSCM membuat algoritme terapi pasien ITP newly diagnosed anak (Gambar 2). Pada Gambar 2 terlihat bila hanya terjadi perdarahan ringan dan trombosit $>20.000 /$ uL maka pasien dapat rawat jalan. Sementara bila perdarahan ringan dan trombosit $\leq 20.000 / \mathrm{uL}$ maka pasien dirawatinap. Bila terjadi perdarahan berat (termasuk yang mengancam jiwa) dan usia $\leq 1$ tahun maka pasien direncanakan untuk pemberian IVIG. Apabila biaya terbatas maka pasien dapat diberikan kortikosteroid. Sementara bila usia pasien $>1$ tahun maka pasien direncanakan untuk mendapatkan kortikosteroid. Selanjutnya bila tidak menunjukkan perbaikan klinis maka pasien direncanakan untuk mendapatkan IVIG.

Apabila pasien tidak menunjukkan perbaikan ataupun relaps setelah pemberian kortikosteroid maka pasien dapat diberikan pilihan pemberian deksametason dosis tinggi ataupun Rituximab. Semuanya ini dipertimbangkan bila pasien mengalami perdarahan berat (Grade $2 \mathrm{C}){ }^{1}$

Faktor prediksi untuk resolusi pada kasus ITP newly diagnosed adalah usia $<5$ tahun dan onset perdarahan $<14$ hari dan jumlah trombosit pada follow-up minggu ke-4 menunjukkan $>100.000 / \mathrm{uL}^{3}$

\section{ITP persisten dan kronik}

Apabila perjalanan penyakit ITP telah mencapai 3 


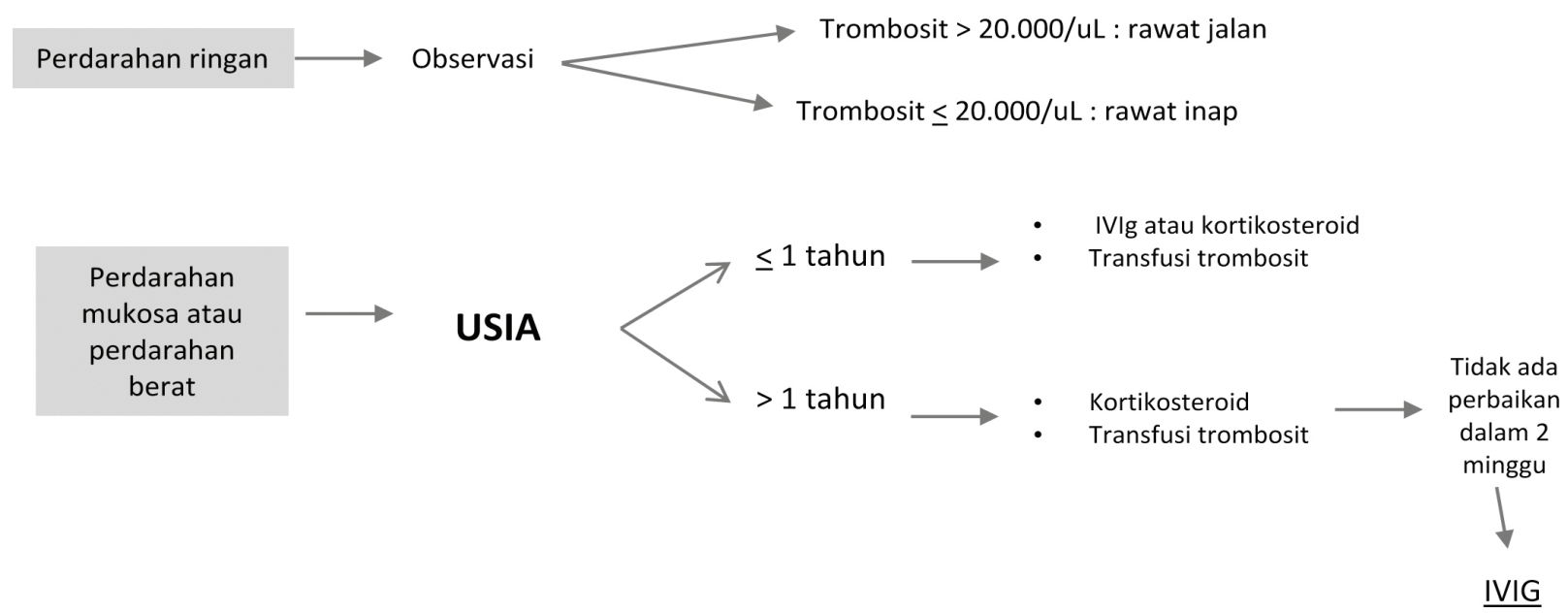

Gambar 2. Alur tata laksana pasien ITP newly diagnosed

bulan maka penyakit ITP dikategorikan sebagai ITP persisten. Pemeriksaan laboratorium yang diperlukan, terdiri dari ${ }^{7}$

- Skrining penyakit autoimun : ANA, anti ds-DNA, Rheumatoid arthritis, C3, C4

- $\quad$ Skrining tiroid : TSH, free T4, antibodi tiroid

- Pengukuran kadar imunoglobulin : IgG, IgA dan IgM

- Fungsi hati

- Tes PCR adanya virus seperti EBV, CMV, parvovirus, Hepatitis C, dan HIV

- H. Pylori

- Pemeriksaan sumsum tulang

- Antibodi antifosfolipid

Berbagai pilihan terapi yang dapat diberikan pada kasus ITP persisten dan kronik, yaitu ${ }^{8}$

- Deksametason $28 \mathrm{mg} / \mathrm{m} 2 /$ hari akan memberikan respons hingga $80 \%$. Biasanya respon akan timbul dalam waktu 3 hari.

- Metil prednisolon dosis tinggi $30 \mathrm{mg} / \mathrm{kg} / \mathrm{hari}$ selama 3 hari yang dilanjutkan dosis $20 \mathrm{mg} / \mathrm{kg} /$ hari selama 4 hari. Respons terjadi pada 60\%-100\% kasus yang terjadi pada 2-7 hari.

- Rituximab $100 \mathrm{mg}$ atau $375 \mathrm{mg} / \mathrm{m} 2 / \mathrm{minggu}$ selama 4 minggu. Respons bervariasi 31\%-79\% kasus.

- Terapi obat atau kombinasi obat, siklosporin A, azatioprin, metil prednisolon, IVIG, anti-D, vinkristin, dan danazol. Sekitar $70 \%$ kasus memberikan respons.
- Splenektomi. Dalam waktu 24 jam pasca splenektomi, jumlah trombosit akan meningkat. Namun demikian, tindakan ini sangat berisiko terjadinya komplikasi sepsis.

Salah satu faktor prediktor perjalanan ITP newly diagnosed menjadi ITP kronik adalah usia saat diagnosis. Penelitian Shim ${ }^{16}$ (2014) memperlihatkan bahwa usia di atas 10 tahun lebih sering menjadi ITP kronik. Penelitian di Turki ${ }^{7}$ pada tahun 2014 juga mendapatkan usia lebih 10 tahun mempunyai kemungkinan 3 kali menjadi ITP kronik $((\mathrm{OR}=3,0, \mathrm{CI}=1,5-5,98)$. Faktor prediktor lain menjadi ITP kronik adalah jenis kelamin perempuan $(\mathrm{OR}=2,55, \mathrm{CI}=1,31-4,95)$. Obat yang digunakan pada kasus ITP tertera pada Tabel $3 .^{18}$

Sebagai kesimpulan, definisi dan klasifikasi ITP telah mengalami perubahan. Berbagai penelitian telah menunjukkan banyak perubahan pada tata laksana ITP. Bila perdarahan yang terjadi adalah ringan, maka dapat dilakukan observasi dengan berbagai pertimbangan. Bila terjadi perdarahan yang berat, pilihan terapi adalah pemberian IVIG, kortikosteroid dan transfusi trombosit. Faktor sosial dalam menentukan pilihan terapi seperti kecemasan orang tua, akivitas anak, dan jarak ke pusat kesehatan harus tetap dipertimbangkan.

\section{Daftar pustaka}

1. Neunert C, Lim W, Crowther M, Cohen A, Solberg Jr L, Crowther MA. The American Society of Hematology 
Tabel 3. Terapi pada kasus ITP anak dan dewasa ${ }^{18}$

\begin{tabular}{llcc}
\hline Obat/terapi & Dosis & $\begin{array}{c}\text { Waktu respons awal } \\
\text { (hari) }\end{array}$ & $\begin{array}{c}\text { Waktu puncak } \\
\text { respons (hari) }\end{array}$ \\
\hline Metil Prednison & $1-4 \mathrm{mg} / \mathrm{kg} / \mathrm{hari}$, po, 1-4 minggu & $4-14$ & $7-28$ \\
Deksametason & $40 \mathrm{mg} / \mathrm{hari}$ po atau IV, 4-6 siklus setiap 14-28 hari & $2-14$ & $4-28$ \\
IVIG & $0,4-1 \mathrm{~g} / \mathrm{kg}$ per dosis, IV (1-5 dosis) & $1-3$ & $2-7$ \\
Anti-D & $75 \mu \mathrm{mg} / \mathrm{kg} / \mathrm{dosis}$, IV & $1-3$ & $3-7$ \\
Rituximab & $375 \mathrm{mg} / \mathrm{m} 2$ per dosis (setiap 4 minggu) & $7-56$ & $14-180$ \\
Splenektomi & Laparoskopi & $1-56$ & $7-56$ \\
Vinkristin & Hingga 2 mg/dosis IV (setiap 4-6 minggu) & $7-14$ & $7-42$ \\
Vinblastin & $0,1 \mathrm{mg} / \mathrm{kg} /$ dosis IV (setiap 6 minggu) & $7-14$ & $28-180$ \\
Danazol & $400-800$ mg po tiap hari & $14-90$ & $30-180$ \\
Azatioprin & $2 \mathrm{mg} / \mathrm{kg}$ perhari, po & $30-90$ & $30-180$ \\
Eltrombopag & $50-75 \mathrm{mg}$ perhari, po & $7-28$ & $14-90$ \\
\hline
\end{tabular}

2011 evidence-based practice guideline for immune thrombocytopenia. Blood 2011;117: 4190-207.

2. Breakey VR, Blanchette VS. Childhood immune thrombocytopenia: a changing therapeutic landscape. Semin Thromb Hemost 2011;37:745-55.

3. Neunert CE. Current management of immune thrombocytopenia. Hematology 2013;2013:276-82.

4. Neunert CE, Buchanan GR, Imbach P, dkk. Intercontinental Childhood ITP study group registry II Participants. Severe hemorrhage in children with newly diagnosed immune thrombocytopenic purpura. Blood 2008;112:4003-8.

5. Yohmi E, Windiastuti E, Gatot D. Perjalanan penyakit purpura trombositopenik imun perjalanan penyakit purpura trombositopenik imun. Sari Pediatri 2007;8:310-5.

6. Witmer CM, Lambert MP, O'Brien SH, Neunert C. Multicenter cohort study comparing U.S management of inpatient pediatric immune thrombocytopenia to current treatment guidelines. Pediatr Blood Cancer 2016;63:122731.

7. Tarantino MD, Danese M, Klaassen RJ, Duryea J, Eisen M, Bussel J. Hospitalizations in pediatric patients with immune thrombocytopenia in the United States. Platelets 2016;27:4728.

8. McGuin C, Bussel JB. Disorders of platelet. Dalam: Lanzkowsky's Manual of Pediatric Hematology and Oncology. 6th ed. Lanzkowsky P, Lipton JM, Fish JD, penyunting. Elsevier; Oxford;2016.h.254-61.

9. Provan D, Stasi R, Newland AC, Blanchette VS, BoltonMaggs P, Bussel JB, dkk. International consensus report on the investigation and management of primary immune thrombocytopenia. Blood 2010;115:168-86.

10. Cuker A, Cines DB, Neunert CE. Controversies in the treatment of immune thrombocytopenia. Curr Opin Hematol
2016, 23:479-485.

11. Neunert CE. Management of newly diagnosed immune thrombocytopenia: can we change outcome? Hematology Am Soc Hematol Educ Program 2017;2017:400-5.

12. De Mattia D, Del Principe D, Del Vecchio GC, Jankovic M, Arrghini A, Giordano P, dkk. Acute childhood idiopathic thrombocytopenic purpura: AIEOP consensus guidelines for diagnosis and treatment. Associazione Italiana di Ematologica e Oncologia Pediatrica. Haematologica 2000;85:420-4.

13. Sruamsiri R, Dilokthornsakul P, Pratoomsoot C, Chaiyakunapruk $\mathrm{N}$. A cost-effectiveness study of intravenous immunoglobulin in childhood idiopathic thrombocytopenia purpura patients with life-treatening bleeding. Pharmacoeconomic. 2014;32:801-13.

14. Choi HS, Ji MH, Kim SJ, Ahn HS. Platelet count recovery after intravenous immunoglobulin predicts a favorable outcome in children with immune thrombocytopenia. Blood Res 2016;51:95-101.

15. Chotsampancharoen T, Sripornsawan P, Duangchoo S, Wongchanchailert M, McNeil E. Predictive factors for resolution of childhood immune thrombocytopenia: Experience from a single tertiary center in Thailand. Pediatr Blood Cancer 2017;64:128-34.

16. Shim YJ, Kim UH, Suh JK, Lee KS. Natural course of childhood chronic immune thrombocytopenia using the revised terminology and definitions of the international working group: a single center experience. Blood Res 2014;49:187-91.

17. Evim MS, Baytan G, Güneş AM. Childhood immune thrombocytopenia: Long-term follow-up data evaluated by the criteria of the International Working Grooup on Immune Thrombocytopenia Purpura. Turk J Haematol 2014;31:32-9.

18. Rodehiero F, Stasi R, Gernsheimer T, Michel M, Provan D, 
Teny Tjitra Sari: Immune thrombocytopenic purpura

Arnold DM, dkk. Standarization of terminology, definitions and outcome criteria ini immune thrombocytopenic purpura of adults and children: report from an international working group. Blood 2009;113:2386-93. 